\title{
THE WRIT OF PROTECTION: FROM PROCEDURAL TO SUBSTANTIVE RIGHTS AND BETWEEN CIVIL AND COMMON LAW ${ }^{1}$
}

\section{INSTRUMENTOS DE PROTEÇÃO CONSTITUCIONAL: DE DIREITOS PROCESSUAIS A DIREITOS SUBSTATIVOS E ENTRE A CIVIL LAW E A COMMON LAW}

Ángel R. Oquendo George J. and Helen M. England Professor of Law, University of Connecticut. Ph.D., M.A. (Philosophy), A.B. (Economics and Philosophy), Harvard University; J.D., Yale Law School, Estados Unidos. E-mail: oquendo@zedat.fu-berlin.de

\begin{abstract}
The article aims to deal with important aspects regarding special instruments used to vindicate fundamental rights and guarantees (called writ of protection). In Brazil, this writ is usually called mandado de segurança. However, there also are other possible tools with similar objectives (not only in Brazil but in all of Iberian America). Despite the variations between the denominations found in different countries, such instruments usually seek similar objectives. As it will be demonstrated, all the species of the writ of protection can be related to an extended concept of jurisdiction and due process of law. In addition to that, these instruments can facilitate the implementation of rights counterbalancing formal inefficiencies and moderating a rigid civil law, as we will see in the present paper.
\end{abstract}

KEYWORDS: American Convention on Human Rights; Civil Procedure; Constitution; Due Process; Habeas Corpus; Human Rights; Injunctions; Judicial Review; Jurisdiction; Precedents; Public Ministry; Stare Decisis; State Action; Summary Judgment; Writ of Protection.

RESUMO: O artigo tem por objetivo tratar de aspectos importantes relativos a instrumentos especiais utilizados para reivindicar direitos fundamentais (denominados writ of protection). No

\footnotetext{
${ }^{1}$ Artigo recebido em 25/11/2021, sob dispensa de revisão.
} 
Revista Eletrônica de Direito Processual - REDP.

Rio de Janeiro. Ano 16. Volume 23. Número 1. Janeiro a Abril de 2022

Periódico Quadrimestral da Pós-Graduação Stricto Sensu em Direito Processual da UERJ

Patrono: José Carlos Barbosa Moreira (in mem.). ISSN 1982-7636. pp. 68-85

www.redp.uerj.br

Brasil, esse writ é usualmente conhecido como mandado de segurança. No entanto, também existem outras possíveis ferramentas com objetivos semelhantes (não só no Brasil, mas em toda a América Ibérica). Apesar das variações entre as nomenclaturas encontradas em diferentes países, tais instrumentos costumam buscar objetivos semelhantes. Como restará demonstrado, todas as espécies de writ of protection podem ser relacionadas a um conceito ampliado de jurisdição e de devido processo legal. Além disso, esses instrumentos podem facilitar a implementação de direitos, contrabalançando ineficiências formais e moderando a rigidez da civil law, como veremos no presente trabalho.

PALAVRAS-CHAVE: Convenção Americana de Direitos Humanos; Direito Processual Civil; Constituição; Devido Processo Legal; Habeas Corpus; Direitos Humanos; Mandado de Segurança; Revisão Judicial; Jurisdição; Súmulas; Ministério Público; Decisão Estatal; Ação Estadual; Julgamento Sumário; Writ of Protection.

Virtually all constitutions in Iberian America enshrine a special litigious implement through which anybody may vindicate her guaranties. ${ }^{2}$ Often, they denominate it "amparo," a word that might denote safekeeping or shelter. The Colombian charter uses instead the term "tutela,"3 which might translate into 'guardianship' or 'defense,' whereas that of Chile opts for that of "recurso de proteccion," or (literally) "protection recourse." "The Brazilian constitutional text, in turn, speaks of a "mandado de segurança," or (possibly) "security mandate."

\footnotetext{
${ }^{2}$ See Const. art. 43 (Arg.); Const. art. 128 (Bol.); Const. art. 5 (Braz.) (LXIX); Const. art. 20 (Chile); Const. art. 86 (Colom.); Const. art. 48 (Costa Rica); Const. art. 72 (Dom. Rep.); Const. art. 88 (Ecuador); Const. art. 247 (El Sal.); Const. art. 265 (Guat.); Const. art. 183 (Hond.); Const. art. 103(I) (Mex.); Const. art. 188 (Nicar.); Const. art. 54 (Pan.); Const art. 134 (Para.); Const. art. 200(2) (Peru); Ley [L.] 16011 (Uru.); Const. art. 27 (Venez.). The Cuban Constitution does not recognize the writ but rather a generic "right to address complaints and petitions to the authorities and to receive a timely, relevant, and grounded responses." Const. art. 61 (Cuba) ("Las personas tienen derecho a dirigir quejas y peticiones a las autoridades, las que están obligadas a tramitarlas y dar las respuestas oportunas, pertinentes y fundamentadas ....”). Finally, Puerto Rico's constitutional charter, which essentially reproduces its U.S. counterpart, does not provide for a protection suit. Const. (P.R.). Consequently, Puerto Ricans apparently vindicate their rights through ordinary civil complaints.

${ }^{3}$ Const. art. 86 (Colom.).

${ }^{4}$ Const. art. 20 (Chile). Curiously, Chilean lawyers use the word 'amparo' to denominate the writ of habeas corpus. See, e.g., Jorge Mario Quinzio Figueiredo, Justicia Constitucional en Chile 78-79 (2000).

${ }^{5}$ Const. art. 5 (LXIX) (Braz.).
} 
Revista Eletrônica de Direito Processual - REDP.

Rio de Janeiro. Ano 16. Volume 23. Número 1. Janeiro a Abril de 2022

Periódico Quadrimestral da Pós-Graduação Stricto Sensu em Direito Processual da UERJ

Patrono: José Carlos Barbosa Moreira (in mem.). ISSN 1982-7636. pp. 68-85

www.redp.uerj.br

This construct seems to have emerged on Mexican soil in the nineteenth century. It appears to have gradually and steadily penetrated courthouses across Iberian American territories. Presently, one encounters it throughout.

Much as its denominations may vary, it seems to pursue similar objectives across the board. Through it, people may rapidly cash in on their rights. They may wield it to stop any perceived abridgement straightaway, while sidestepping the infamously inefficacious ordinary road to recognition.

The decisional entity must prioritize their request. It must deploy tailored procedural rules. Its occupant must rule within a short timeframe. At the onset, she may approve preliminary injunctions.

Typically, the ruling binds barely the litigants. It does not posit a precedent. A subsequent, a similarly situated suitor would have to relitigate. She may cite the prior opinion as a source of persuasive reasons, not as a compulsory commandment.

Perceptibly, the proceedings possess a comparable construction all over. The difference alongside the devil might dwell in the details. Each nation appears to have elaborated its own peculiar parameters. It might have borrowed from or distanced those of its neighboring sisters.

In Argentina and Brazil, the adjudication unfolds strictly summarily on the basis of documentary corroboration. ${ }^{6}$ It might resemble that on a motion for summary judgment. In Mexico and beyond, pleaders may apparently introduce evidence of any sort, including testimonial. Evidently, they benefit from more time to prove and argue.

The extant regimens diverge on state action, alternating between requiring it and not. Concurrently, they depart from one another on whether they extend to non-constitutional entitlements or may target judges. Contrary to their regional peers, Argentina and Paraguay expressly authorize adjudicators to quash unconstitutional statutory provisions. ${ }^{7}$

\footnotetext{
${ }^{6}$ The Argentine Writ of Protection Act declares the action inadmissible "whenever determining the alleged invalidity of the act would require ample argumentation or proof ...." L. 16.986, art. 2(d) (Arg.) (1966) ("La acción de amparo no será admisible cuando ... [1]a determinación de la eventual invalidez del acto requiriese una mayor amplitud de debate o de prueba ...."). Brazil's Constitution, in turn, establishes that the writ lies to protect "summarily and clearly ascertainable" entitlements. Const. art. 5 (LXIX) (Braz.) ("[O] mandado de segurança para [visa] proteger direito líquido e certo ....").

${ }^{7}$ Const. art. 43 (Arg.); Cd. Pro. Civ. art. 582 (Para.).
} 
Revista Eletrônica de Direito Processual - REDP.

Rio de Janeiro. Ano 16. Volume 23. Número 1. Janeiro a Abril de 2022

Periódico Quadrimestral da Pós-Graduação Stricto Sensu em Direito Processual da UERJ

Patrono: José Carlos Barbosa Moreira (in mem.). ISSN 1982-7636. pp. 68-85

www.redp.uerj.br

In the teeth of these divergences, the sundry schemes seem to converge, conspicuously so in contrast to that alternatively tendered by northerly neighbor. After all, they overwhelmingly display the sketched skeletal structure, which evokes that of the German constitutional grievance, ${ }^{8}$ especially in its extraordinariness. In the United States, one stakes such claims ordinarily.

Throughout Iberian America, constitutionally specialized courts or chambers habitually hear the conclusive argumentation. To a degree, they might mirror their correspondents in Germany or France. Notoriously, the United States offers nothing of the like.

The discussed device might have developed along multifarious interlinked developmental lines within its geographic terrain. It might have launched and traveled at a tear as part of a broader transcontinental conversation on justiciability and constitutionalism. The conversational exchanges appear to have persisted up to the present.

The pioneering rendering might constitute the most complex one. Directly or indirectly, it might have influenced its analogues abroad. Hence, a few reflections on it might provide a helpful overview. They might illuminate evolutions elsewhere.

This quaint contribution seems to have cropped up in the 1840s. It featured in the 1841 Yucatan Constitution. ${ }^{9}$ The nationwide version arrived with the 1847 Constitutive and Reformative Act, which modified the 1824 federal charter. ${ }^{10}$ It might represent an attempt to incorporate judicial review as forged north of the border in Marbury v. Madison. ${ }^{11}$ Spanish, French, and Mexican influences permeated parallelly. ${ }^{12}$

The current instrument of governance positions the federation's forums at the forefront. ${ }^{13}$ It bids them to effectuate all "guaranties" granted by it. ${ }^{14}$ Its counterparts in Argentina, Bolivia,

\footnotetext{
${ }^{8}$ Grundgesetz für die Bundesrepublik Deutschland [Basic Law] art. 93(1)(4a) (Ger.); see Héctor Fix-Zamudio, El juicio de amparo mexicano y el recurso constitucional federal alemán (breves reflexiones comparativas), Boletín Instituto de Investigaciones Jurídicas, Nueva Serie 461-488 (Year XXVI; No. 77) (May-Aug. 1993).

${ }^{9}$ Const. arts. 62, 80 (Yucatán) (Mex.) (1841).

${ }^{10}$ Acta Constitutiva y de Reformas art. 25 (Mex.) (1847).

115 U.S. 137 (Cranch) (1803).

${ }^{12}$ Héctor Fix-Zamudio, Ensayos sobre el derecho de amparo §§ 13-24, at 22-25 (1999).

${ }^{13}$ Const. art. 103(I) (Mex.).

${ }^{14}$ Id. ("Los tribunales de la Federación resolverán toda controversia que se suscite: (I) Por normas generales, actos u omisiones de la autoridad que violen . . . las garantías otorgadas para su protección por esta Constitución ... ..”).
} 
Revista Eletrônica de Direito Processual - REDP.

Rio de Janeiro. Ano 16. Volume 23. Número 1. Janeiro a Abril de 2022

Periódico Quadrimestral da Pós-Graduação Stricto Sensu em Direito Processual da UERJ

Patrono: José Carlos Barbosa Moreira (in mem.). ISSN 1982-7636. pp. 68-85

www.redp.uerj.br

Brazil, Guatemala, and Paraguay promote like broadness. ${ }^{15}$ Notwithstanding, they safeguard solely constitutional or cardinal entitlements in other locations. ${ }^{16}$

Paradigmatically, a definitive disposition does not boast repercussions beyond itself. ${ }^{17}$ It may illegalize the denounced conducts with respect to the disputants, not per se. Subsequently, others may not categorically bank on it. Rather, they must argue anew. Their allegations may bring it up persuasively, not peremptorily.

Back at the birthplace of the entire story recounted, this "principle of relativity" 18 has chalked up fame as the "Otero formula" after its introduction by scholar and politician Mariano Otero in the aforementioned 1847 amendatory enactment. ${ }^{19}$ It might reflect characteristically civil-law concerns with overstretches emanating from courtrooms. This compromise between the extremes of absolute deference to and full-fledged monitoring of those politically placed at the helm appears to have attained ample adherence continentally.

A curious exception to this relativization has evolved, though. The judicial intermediaries of (1) ultimate and (2) penultimate resort may impose their caselaw on others within their ambit so long as they satisfy these strict conditions: The holdings of the former must have gathered the support, in "five consecutive, uninterrupted decisions," of "at least eight [out

\footnotetext{
${ }^{15}$ See Const. art. 43 (Arg.); Const. art. 128 (Bol.); Const. art. 5 (LXIX) (Braz.); Const. art. 265 (Guat.); Const. art. 134 (Para.).

${ }^{16}$ El Salvador, Honduras, Nicaragua, Panama, Peru, and Uruguay limit the writ to constitutional entitlements. See Const. art. 247 (El Sal.); Const. art. 183 (Hond.); Const. art. 188 (Nicar.); Const. art. 54 (Pan.); Const. art. 200(2) (Peru); Law 16011 art. 1 (Uru.) (1988). Chile allows the action to protect only a specific list of constitutional entitlements, while the Colombian writ secures exclusively "fundamental constitutional rights." See Const. art. 20 (Chile); Const. art. 86 (Colom.) ("Toda persona tendrá acción de tutela para reclamar . . . la protección inmediata de sus derechos constitucionales fundamentales ....”). Costa Rica, Ecuador, and Venezuela authorize protection suits to safeguard constitutional plus fundamental international, inalienable, and ordinary international rights respectively. See Const. art. 48 (Costa Rica); Const. art. 88 (Ecuador); Const. art. 27 (Venez.). In the Dominican Republic, plaintiffs may file a protection complaint for the "protection of fundamental rights." Const. art. 72 (Dom. Rep.) ("Toda persona tiene derecho a una acción de amparo para . . . la protección inmediata de sus derechos fundamentales ....").

${ }^{17}$ See Const. art. 107(II) (Mex.); L. de Amparo, Reglamentaria de los Artículos 103 y 107 de la Constitución Política de los Estados Unidos Mexicanos [Writ of Protection Act, Regulatory of Articles 103 and 107 of the Political Constitution of the Mexican United States], art. 76 (1936).

${ }^{18}$ Ignacio Burgoa adopts this term. Ignacio Burgoa, El Juicio de Amparo 275 (1994) (“[L]os constituyentes del 17 ... respetaron la fórmula de Otero, tal vez por haberles parecido perfecta para connotar y delimitar el principio de relatividad de la cosa juzgada en el juicio de garantías .... ."); id. at 529 ("Principio de relatividad.").

${ }^{19}$ Id. at 275; Acta Constitutiva y de Reformas art. 25 (Mex.) (1847). See Fix-Zamudio, supra note 12, § 29, at 26.
} 
Revista Eletrônica de Direito Processual - REDP.

Rio de Janeiro. Ano 16. Volume 23. Número 1. Janeiro a Abril de 2022

Periódico Quadrimestral da Pós-Graduação Stricto Sensu em Direito Processual da UERJ

Patrono: José Carlos Barbosa Moreira (in mem.). ISSN 1982-7636. pp. 68-85

www.redp.uerj.br

of the eleven] justices [of the] Plenum or four" out of the quintet of either "Chamber" within. ${ }^{20}$

Those of the latter must have themselves landed the approval of a decisional fivesome characterized by consecutiveness plus unanimity. ${ }^{21}$ These yardsticks apply primordially within the realm under exploration, albeit they have stretched out to envelop all others. ${ }^{22}$

Equally easing without eliminating the bias against stare decisis, the constitutionally chief adjudicating organ may limitedly render its doctrines outwardly obligatory along other Latin American latitudes. As an illustration, it must embrace them thrice and consecutively in Guatemala. $^{23}$ Consonantly, two-thirds of its members must endorse them on reiterated occasions, upon discord among lower adjudicative bodies, and before situations of "serious legal uncertainty" in Brazil. ${ }^{24}$ As a mark of distinction, the endorsers there must manifest their endorsement in reiteration yet need not number their iterations.

Extraordinarily, such a tribunal saddles its jurisprudences on others under it, without limitations, in Costa Rica or Venezuela. ${ }^{25}$ Swayed by the United States, it may likewise head in this direction in Puerto Rico, distinctively constraining itself together with its hierarchical inferiors. ${ }^{26}$ Regardless, the Puerto Rican system, like that of Cuba and unlike their parallels in the region, has not waived the writ under the microscope through.

\footnotetext{
${ }^{20}$ L. de Amparo, Reglamentaria de los Artículos 103 y 107 de la Constitución Política de los Estados Unidos Mexicanos, art. 192 (Mex.) (1936) ("Las resoluciones constituirán jurisprudencia, siempre que lo resuelto en ellas se sustenten en cinco sentencias ejecutorias ininterrumpidas por otra en contrario, que hayan sido aprobadas por lo menos por ocho ministros si se tratara de jurisprudencia del pleno, o por cuatro ministros, en los casos de jurisprudencia de las salas.").

${ }^{21}$ Id.

${ }^{22}$ L. Orgánica del Poder Judicial de la Federación [Organic Law on the Federation's Judicial Power] art. 177 (Mex.) (1995).

${ }^{23}$ L. de Amparo, Exhibición Personal y de Constitucionalidad [Writ of Protection, Habeas Corpus, and Constitutionality Act], Decreto No. 1-86, art. 43 (1986) (Guat.).

${ }^{24}$ Const. art. 103(A) (Braz.).

${ }^{25}$ L. de la Jurisdicción Constitucional [Constitutional Jurisdiction Act], L. 7135, art. 13 (Costa Rica) (1989); Const. art. 335 (Venez.).

${ }^{26}$ See García Fernández, ex parte, 44 D.P.R. 296 (1932); Capestany v. Capestany, 66 D.P.R. 764 (1946); González Natal v. Merck Sharp \& Dohme Química de Puerto Rico, Inc., 166 D.P.R. 659, 688 (2006) (Hernández Denton, concurring).
} 
Traditionally, Mexico seems to have purely enabled the securement of basic rights. Nevertheless, it has enormously expanded the proffered possibilities. ${ }^{27}$ Currently, one may "challenge" through it any official comportment, "resolution," or "precept.,"28

Doubtless, these manifold possible paths deviate from one another. Concomitantly, they intricately interlock. In fact, this intranational variation on a theme and the international one referred to earlier echo each other. Despite this echo, they distinctly differ, relating to one another as division and multiplication.

Héctor Fix-Zamudio breaks the beast down into habeas corpus (to test detainments), contestation of laws, and cassation, conjointly with the administrative and agrarian alternates. ${ }^{29}$ Probably, commentators could concoct as many ways to categorize it as to skin a cat. At any rate, they might expound it most perspicuously by focusing on the kind of act it aspires to contest and accordingly trifurcating it based on the typically acting governmental branch.

(1) First, a claimant might train her artillery on administratively articulated deportments that allegedly abridge her guaranties. Illustratively, she might pursue the policemen who fined her for delivering a subversive speech in a town square. Of course, if they locked her up, her libel might function as an entreaty to have her confinement proofed.

Overall, she may oppose administrators so long as she enjoys no equivalent means of opposition within their agency. On the flip side of the coin, they may expect her to exhaust internal resources. She may defy this expectation, though, if the internally prescribed preconditions for a stay exceed those imposed externally. ${ }^{30}$

The importance to her of this whole option might have diminished with the expansion of administrative adjudicatory institutions at the federal or state level. ${ }^{31}$ As indicated, she would have to resort to them. Presumably, her eventual confrontation of their adjudicative activity might materialize in the manner described later under the third classification.

\footnotetext{
${ }^{27}$ Fix-Zamudio, supra note $12, \S 3$, at 19.

${ }^{28}$ Id. ("[E]n nuestros días, salvo contadas excepciones, esta institución sirve para impugnar todos los actos, resoluciones y preceptos de nuestro ordenamiento jurídico.”).

${ }^{29}$ Id. $\S \S 41-104$, at 30-47.

${ }^{30}$ Const. (Mex.) art. 107(IV).

${ }^{31}$ Fix-Zamudio, supra note $12, \S \S 83-87$, at $41-42$.
} 
Revista Eletrônica de Direito Processual - REDP.

Rio de Janeiro. Ano 16. Volume 23. Número 1. Janeiro a Abril de 2022

Periódico Quadrimestral da Pós-Graduação Stricto Sensu em Direito Processual da UERJ

Patrono: José Carlos Barbosa Moreira (in mem.). ISSN 1982-7636. pp. 68-85

www.redp.uerj.br

Anyway, she might administratively confront the judiciary or legislature. For example, her confrontational energies might seize on an arbitrary ban on her lawyering in a particular courthouse. Or they might turn toward an illegitimate denial of access to key congressional documents.

The variant designed for the agricultural world might fall under this inaugural category. It specifically serves to battle actual or potential deprivations of "ownership," "possession," or "enjoyment" of land, water, pasture, or woodland belonging to a communal landowner or population. ${ }^{32}$ Commonly, they would appear to count as executive or administrative. Naturally, a legislatively or an adjudicatively colored configuration might qualify them for the remaining classes in this enumeration.

As parliamentarily fashioned, this precise tool purports to expedite the enforcement of land-reform entitlements fought for during the 1910 Revolution. ${ }^{33}$ Basically, it permits peasant or indigenous communities to shield their collectively owned properties. Its formally formulated prescriptions come across (perchance paradoxically) as informal. Irrespective, they oblige the adjudicator to rectify mistakes in the complaint, ${ }^{34}$ argument, ${ }^{35}$ evidentiary submission, ${ }^{36}$ or appellate petition. ${ }^{37}$

(2) Secondly, the prosecution against laws covers not only statutes but also executively sanctioned decrees or administratively generated regulations. It might have comparably drawn its inspirations from the United States. In counterpoint, its lack of generalized effects obviously separates it from its northern opposite number.

\footnotetext{
${ }^{32}$ Const. (Mex.) art. 107(II).

${ }^{33}$ Fix-Zamudio, supra note 12, $§ 94-95$, at 44.

${ }^{34}$ L. de Amparo, Reglamentaria de los Artículos 103 y 107 de la Constitución Política de los Estados Unidos Mexicanos, art. 227 (Mex.) (1936). This obligation applies to other protection suits too. Id. art. 76b; Const. (Mex.) art. 107(II).

${ }^{35}$ L. de Amparo, Reglamentaria de los Artículos 103 y 107 de la Constitución Política de los Estados Unidos Mexicanos, art. 227 (Mex.) (1936).

${ }^{36}$ Const. (Mex.) art. 107(II); L. de Amparo, Reglamentaria de los Artículos 103 y 107 de la Constitución Política de los Estados Unidos Mexicanos, art. 225 (Mex.) (1936).

${ }^{37}$ L. de Amparo, Reglamentaria de los Artículos 103 y 107 de la Constitución Política de los Estados Unidos Mexicanos, art. 227 (Mex.) (1936).
} 
Concretely, a proclamation of invalidity exclusively profits or prejudices the participants in the litigation. ${ }^{38}$ As such, it boils down to an affirmation of inapplicability to them. Nonparties seem to remain beholden to the contextually invalidated norm. Scarcely upon its universalized invalidation at the two topmost echelons of the bench in observance of the previously pinpointed prerequisites may they escape this fate.

The filer would appear to have to process the entity responsible for the normative target's adoption, such as the parliament or the executive. She must, as all others in this general domain, demonstrate an impact on her "legal interests." 39 Besides, her challenge must zoom in on selfexecuting legislation, which does not ride on supplemental legislative or administrative exertions for its effectivity. ${ }^{40}$

She must lodge her accusation in the districted locality where the encroachment purportedly occurred. ${ }^{41}$ Upon an initial adjudgment, an appeal as of right before a circuit panel lies. ${ }^{42}$ In contradistinction, the Supreme Court uniquely reviews matters raised importantly and transcendentally. ${ }^{43}$

These suits clearly contrast with those locally delineated to target unconstitutionality. For starters, they welcome anyone as a complainant, not just select candidates, like the Public Ministry, political organizations, or $33 \%$ of the representatives of a parliamentary assembly. ${ }^{44}$ As a follow-up, the nationally lowest, not the highest, judicial intermediary appraises the postulations and proofs. For closers, it may, as already remarked, discard the spotlighted standards vis-à-vis the dispute at bar, not in themselves.

(3) Thirdly, an individual may proceed against a courtroom determination. She might attack it, say, for unjustifiably exonerating her discriminatory employer. If the exoneration

\footnotetext{
${ }^{38}$ See Const. art. 107(II) (Mex.).

${ }^{39}$ L. de Amparo, Reglamentaria de los Artículos 103 y 107 de la Constitución Política de los Estados Unidos Mexicanos, art. 73(V) (Mex.) (1936) ("El juicio de amparo es improcedente: V.- Contra actos que no afecten los intereses jurídicos del quejoso.”).

${ }^{40}$ Id. art. 73(VII).

${ }^{41}$ Const. (Mex.) art. 107(VII).

${ }^{42}$ Id. art. 107 (VIII).

${ }^{43} \mathrm{Id}$.

${ }^{44}$ See Const. art. 105(II) (Mex.).
} 
exemplarily rested on multiple edicts, her attack may have them collaterally set aside. Once again, it would thus sheerly shelter her, in this concrete context, from them.

Usually, she must wait until the end of the first through the final instance ${ }^{45}$ Contrariwise, her filing may follow the former if she risks irremediable injury. ${ }^{46}$ It may adversarially aim at administratively, civilly, or criminally vested adjudicating organs. Effectively, she would thereby score an additional round of appellate appraisal.

A circuit panel, not the triers at the relevant district, would docket her papers. ${ }^{47}$ Normally, she or her opponent may not appeal the outcome. Exceptionally, the controlling criterion invites them to seek extra examination when a "law's constitutionality or the direct interpretation" of a constitutional tenet is at play and the appeal rings "important and transcendent. ${ }^{348}$ In essence, it accords her or him an invitation to step into the shoes of the petitioners in the notorious case Mexican Sugar Workers Union v. Hernández Rivera. ${ }^{49}$

Patently, she might complain that the supposedly violative orders led to her incarceration. Then, her pleadings would essentially question it and solicit her discharge. Consequently, the present breakdown vouchsafes her, when detained, a twosome of tracks depending on whether her detention stems from the administration or the judiciary.

Curiously, the actualization armament on the table allows her to controvert any adjudged settlement, not just one that undermines specified safeguards. In this vein, it derives from and ultimately replaced the cassation, which hailed from France via Spain as a plea to vacate. ${ }^{50}$ Consistently with this derivation, the deliberating jurists correct any erstwhile exegetical error. Through such corrections, they might recall their colleagues on the French ordinary top tribunal.

\footnotetext{
${ }^{45}$ Const. art. 107(III) (Mex.).

${ }^{46}$ Id.

${ }^{47}$ Id. art. $107(\mathrm{~V})$.

${ }^{48}$ Id. art. 107(IX).

${ }^{49}$ Suprema Corte de Justicia de la Nación [Sup. Ct.] [National Supreme Court of Justice], Segunda Sala [Second Chamber], Apr. 17, 2001, [Sindicato de Trabajadores de la Industria Azucarera v. Hernández Rivera,] Amparo directo en revisión [Direct Writ of Protection upon Revision] No. 1124/2000, Registro [Reg.] No. 7163, Semanario Judicial de la Federación y su Gaceta [Weekly Judicial Journal and its Gazette], Novena Época [Ninth Epoch], Tomo [Tome] III, Mayo [May] de [of] 2001, página [Page] 322 (Mex.) (on file with author).

${ }^{50}$ Fix-Zamudio, supra note $12, \S 26$, at 204-05.
} 
Revista Eletrônica de Direito Processual - REDP.

Rio de Janeiro. Ano 16. Volume 23. Número 1. Janeiro a Abril de 2022

Periódico Quadrimestral da Pós-Graduação Stricto Sensu em Direito Processual da UERJ

Patrono: José Carlos Barbosa Moreira (in mem.). ISSN 1982-7636. pp. 68-85

www.redp.uerj.br

This ample jurisdiction seems to repose on an expansive exegesis of the concept of due process. ${ }^{51}$ It appears to build on the controversial idea that any legal misapplication violates the notion of legality. Unimaginable north of the frontier, such an approach might have prevented federalism from judicially flourishing in Mexico. It might have gained acceptance because of a strong tradition of centralism.

This jurisdictional grab might have transpired during the post-independence era as lawyerly elites operating in sizable cities harboring federal forums arrogated to themselves the prerogative to check dispositional decision-making every where. It suffered criticisms from early on and from different angles. In 1906, Emilio Rabasa repudiated it for distorting the spirit of the constitutionally apposite passages and overburdening the premier adjudicatory institution. ${ }^{52}$ Others, such as Niceto Alcalá-Zamora y Castillo, proposed preserving it as a narrow prayer for vacation, while jettisoning its dubious jurisprudential rationalizations. ${ }^{53}$ Perhaps the decentralization drive that began in 2000 with the demise of the Institutional Revolutionary Party's political hegemony will culminate with a reassessment of this peculiarity.

In any event, some countries have precedentially instituted this armamentarium of vindication. Invariably, they seem to have successively codified or constitutionalized it. The discussion will now crack into a couple of conspicuous exemplifications.

Argentina joined the club of supporters of this style of substantiation in 1957. It renewed its membership in 1958. Its enrollment and renewal respectively ensued upon the "leading"

\footnotetext{
${ }^{51}$ Const. arts. 14, 16 (Mex.).

${ }^{52}$ Emilio Rabasa, El artículo 14, estudio constitucional, y el juicio constitucional, orígenes, teoría y extensión 5194 (5th ed. 1984). See Fix-Zamudio, supra note 12, § 56, at 213; Charles A. Hale, The Civil Law Tradition and Constitutionalism in Twentieth Century Mexico: The Legacy of Emilio Rabasa, 18 Law \& Hist. Rev. 257, 267-268 (2000).

${ }^{53}$ Niceto Alcalá-Zamora y Castillo, Amparo y casación 540-541 (1960). See Fix-Zamudio, supra note 12, § 55, at 213.

${ }^{54}$ See, e.g., Jorge Alejandro Amaya, Aportes a los procedimientos de protección al consumidor que consagra el Artículo 42 de la Constitución Nacional at 4 (manuscript) (on file with author) originally published in 1 Revista jurídica de la Universidad de Ciencias Empresariales y Sociales (UCES) (primavera-verano) (1999) ("La Corte Suprema de Justicia de la Nación acogió los derechos de 'tercera generación' . . en los 'leading case' 'Miguel Ángel Siri' y 'Samuel Kot S.R.L.”); Jorge A. Rojas, Un “nuevo molde” para el amparo, 1 Revista latinoamericana de derecho 425, 426 (2004).
} 
Revista Eletrônica de Direito Processual - REDP.

Rio de Janeiro. Ano 16. Volume 23. Número 1. Janeiro a Abril de 2022

Periódico Quadrimestral da Pós-Graduação Stricto Sensu em Direito Processual da UERJ

Patrono: José Carlos Barbosa Moreira (in mem.). ISSN 1982-7636. pp. 68-85

www.redp.uerj.br

Siri v. Police Commissioner and Kot, L.L.C., v. Fistein, ${ }^{55}$ which the succeeding paragraphs will briefly consider in alternation.

Initially, Ángel Siri attempted to obtain habeas relief after the police arbitrarily shut down his newspaper. ${ }^{56}$ Having endured no impairment of his "physical liberty," however, he failed before the competent trier. ${ }^{57}$ Afterward, the utmost national adjudicative body "reverse[d]," 58 opening the door to rapid redress upon violations of other commitments. Particularly, it detected a "clear" infringement upon "freedom of the press and to work." 59

In tune, Samuel Kot, the "owner of a textile plant," stood up against his operatives, who had occupied his company's premises to protest the dismissal of a duo of union heads in the aftermath of a strike. ${ }^{60}$ Showing little sympathy for the workforce and committing to redress "all manifestly illegal restrictions ... whenever relying on [regular formalities] would result in serious and irreparable harm," the justices sided with him upon the invocation of the reliable "remedy" pledged by the Universal Declaration of Human Rights. ${ }^{61}$ Anyhow, they insisted on "ponderation" or "prudence," to avoid utilizing this contraption to answer questions craving for "extensive debate."62 Significantly, the majority blessed the businessman's summoning of

${ }^{55}$ Ct. Sup., Dec. 27, 1957, Siri, Ángel s./, [Siri v. Comisario de Policía,] Fallos [Opinions]: 239:459 (Arg.) (on file with author); Ct. Sup., Sept. 5, 1958, Kot, Samuel S.R.L. s./, [Kot v. Finstein,] Fallos: 241:291 (Arg.) (on file with author).

${ }^{56}$ Ct. Sup., Dec. 27, 1957, Siri, Ángel s./, Fallos 239:459, at 462.

${ }^{57}$ Id. ("Reiterada por el solicitante la declaración pedida . . ., el juez resolvió no hacer lugar a ella en razón de no tratarse en el caso de un recurso de hábeas corpus, el cual sólo protege la libertad física o corporal de las personas ....").

${ }^{58}$ Id. ("[S]e revoca la sentencia apelada.").

${ }^{59}$ Id. (“[L]a garantía de la libertad de imprenta y de trabajo . . . se halla evidentemente restringida . . . .").

${ }^{60}$ Ct. Sup., Sept. 5, 1958, Kot, Samuel S.R.L. s./, [Kot v. Finstein,] Fallos: 241:291, at 296-97 ("La firma Samuel Kot S.R.L., propietaria de un establecimiento textil . . . mantiene . . . un conflicto con su personal obrero. La . . . firma patronal dispuso la concurrencia de los obreros a su trabajo . . . con excepción de los delegados Arón Fistein y Aníbal Villamayor. . . L La empresa se negó a reincorporar a los obreros que había despedido y entonces éstos y otros compañeros ocuparon la fábrica . . . y se mantienen en ella hasta ahora . . ..”).

${ }^{61} \mathrm{Id}$. at 302 ("Siempre que aparezca . . . la ilegitimidad de una restricción cualquiera a alguno de los derechos esenciales de las personas así como el daño grave e irreparable que se causaría remitiendo el examen de la cuestión a los procedimientos ordinarios, .. . corresponderá que los jueces restablezcan de inmediato el derecho restringido por la rápida vía del recurso de amparo.”); id. (“Toda persona tiene derecho a un recurso efectivo . . . que la ampare contra actos que violen sus derechos fundamentales ....”) (quoting Universal Declaration of Human Rights, G.A. Res. 217 (III) A, art. 8 (Dec. 10, 1948)).

${ }^{62}$ Id. ("[L]os jueces deben extremar la ponderación y la prudencia . . . a fin de no decidir, por el sumarísimo procedimiento de esta garantía constitucional, cuestiones susceptibles de mayor debate y que corresponda resolver de acuerdo con los procedimientos ordinarios."). 
Revista Eletrônica de Direito Processual - REDP.

Rio de Janeiro. Ano 16. Volume 23. Número 1. Janeiro a Abril de 2022

Periódico Quadrimestral da Pós-Graduação Stricto Sensu em Direito Processual da UERJ

Patrono: José Carlos Barbosa Moreira (in mem.). ISSN 1982-7636. pp. 68-85

www.redp.uerj.br

private persons. With this blessing, it seemingly inaugurated a transnational trend. ${ }^{63}$ Nonetheless, several sovereign dissenters have arisen across the continent. ${ }^{64}$

Indeed, the Argentine standardizing codification itself domestically dissented on point in 1966 but had to buckle under the countermand of a 1967 amendment to the Code of Civil and Commercial Procedure and of the 1994 pertinent constitutionally crafted strictures. ${ }^{65}$ Correlatively, it had to yield to the liberality of these in the specification of the encompassed pledges, against its own restriction to "explicitly or implicitly" constitutionalized guaranties. ${ }^{66}$

Still, the prescripts passed by lawmakers, insofar as not constitutionally or statutorily superseded, ostensibly continue in force as to the core and particularities. Mostly, they reassert their adjudicated antecessors, like those pertaining to abbreviation, swiftness, or subsidiarity, ${ }^{67}$ which conform with those ubiquitously applicable in Iberian America. ${ }^{68}$ By and large, the Constitution concurs too. Narrowly, it might somewhat demarcate itself by demanding the inexistence of a "more appropriate," not any old, alternative. ${ }^{69}$

In 1999, the Dominican Republic had yet to jump on the bandwagon. It dared the jump quite dramatically that year. Its arch authoritative jurists unanimously reckoned the effectuation

\footnotetext{
${ }^{63}$ See Const. art. 43 (Arg.); Const. art. 128 (Bol.); Auto Acordado de la Excma. Corte Suprema sobre tramitación del Recurso de Protección [Supreme Court Decree on the Writ of Protection], arts. 3, 12 (Chile) (1977); Const. art. 86 (Colom.); Const. art. 72 (Dom. Rep.); Const. art. 88 (Ecuador); Const. art. 134 (Para.); Const. art. 200(2) (Peru); L. 16.011, art. 1 (Uru.) (1988); L. Orgánica de Amparo sobre Derechos y Garantías Constitucionales [Organic Law on the Writ of Protection for Rights and Guaranties] [L. Orgánica de Amparo sobre Derechos y Garantías Const.], art. 2 (Venez.) (1988).

${ }^{64}$ See Const. art. 5 (LXIX) (Braz.); L. de la Jurisdicción Constitucional, L. 7135, art. 29 (Costa Rica) (1989); L. de Procedimientos Constitucionales [Constitutional Procedures Act], art. 12 (El Sal.) (1960); L. de Amparo, Exhibición Personal y de Constitucionalidad, Decreto No. 1-86, art. 8 (Guat.) (1986); Const. art. 183 (Hond.); Const. art. 103(I) (Mex.); Const. art. 188 (Nicar.); Const. art. 54 (Pan.).

${ }^{65}$ Código Procesal Civil y Comercial de la Nación [Commercial and Civil Procedural Code of the Nation], L. 17454 art. 321(1) (1967) (Arg.); Const. art. 43 (Arg.).

${ }^{66}$ L. 16.986, arts. 1, 8 (Arg.) (1966).

${ }^{67}$ Id. 1, 2(a), 2(d).

${ }^{68}$ See, e.g., Const. art. 129(I) (Bol.); Const. art. 86 (Colom.); L. de Procedimientos Constitucionales, Decreto No. 2996, art. 12 (El Sal.) (1960); L. de Amparo, Exhibición Personal y de Constitucionalidad, Decreto No. 1-86, art. 19 (Guat.) (1986); Const. art. 134 (Para.); Writ of Protection Act, L. 16.011 (Uru.) (1988) art. 2; L. Orgánica de Amparo sobre Derechos y Garantías Const., art. 5 (Venez.) (1988).

${ }^{69}$ Const. art. 43 (Arg.) ("Toda persona puede interponer acción expedita y rápida de amparo, siempre que no exista otro medio judicial más idóneo .....”).
} 
Revista Eletrônica de Direito Processual - REDP.

Rio de Janeiro. Ano 16. Volume 23. Número 1. Janeiro a Abril de 2022

Periódico Quadrimestral da Pós-Graduação Stricto Sensu em Direito Processual da UERJ

Patrono: José Carlos Barbosa Moreira (in mem.). ISSN 1982-7636. pp. 68-85

www.redp.uerj.br

weapon at stake as one guaranteed under the American Convention on Human Rights. They deemed it as such automatically integrated into local positive law. ${ }^{70}$

The petitioners averred that the bench below had deprived them of the processing duly owed to them in umpiring their removal of a pair of their employees. ${ }^{71}$ They invoked inter alia the treaty's assurance of a "simple and prompt . . . or any other effective recourse . . against" impingements upon congressionally, constitutionally, or conventionally conceded "fundamental" entitlements. ${ }^{72}$ In response, Productos Avon compels the institutionalization of "a special mechanism" to enforce guaranties. ${ }^{73}$ It claims for itself the power to define the intricacies in the face of the legislators' inaction. ${ }^{74}$

Under the furnished definition, a tight daily schedule dictates the pace. "The plaintiff must request" repair "within fifteen days of the" transgression. She must receive a "hearing" within three. The verdict must issue within five. She or her rival "must appeal . . within three." The appeal "must meet the same ... deadlines" as the trial. ${ }^{75}$

En route, she does not have to pay "costs."76 Undoubtedly, this exemption should encourage her efforts. To boot, she may sue (1) judges on their nonjudicial functions as well as

\footnotetext{
${ }^{70}$ See Ct. Sup., Feb. 24, 1999, [Productos Avon, S.A. v. Sala No. 2 del Juzgado de Trabajo del Distrito Nacional], Sentencia No. 40394 (Dom. Rep.) (on file with author).

${ }^{71}$ Id. at 2.

${ }^{72}$ Id. at 3 ("Toda persona tiene derecho a un recurso sencillo y rápido o a cualquier otro recurso efectivo ante jueces o tribunales competentes, que la ampare contra actos que violen sus derechos fundamentales . . ..") (quoting Organization of American States, Convención Americana de Derechos Humanos art. 25(1), Nov. 22, 1969, O.A.S. T.S. No. 36, 1144 U.N.T.S. 123).

${ }^{73}$ Id. at 3 ("[E]l recurso de amparo, como mecanismo protector de la libertad individual en sus diversos aspectos, no debe ser excluido como remedio procesal específico para solucionar situaciones creadas por personas investidas de funciones judiciales ....").

${ }^{74}$ Id.

${ }^{75}$ Id. at 4 ("[E]l impetrante deberá interponer la acción de amparo contra el acto arbitrario u omisión, dentro de los quince (15) días en que se haya producido el acto u omisión de que se trate; . . la audiencia para el conocimiento de la acción, deberá ser fijada para que tenga lugar dentro del tercer día de recibida la instancia correspondiente. [E]l juez deberá dictar su sentencia dentro de los cinco días que sigan al momento en que el asunto quede en estado; el recurso de apelación, que conocerá la corte de apelación correspondiente, deberá interponerse dentro de los tres días hábiles de notificada la sentencia, el cual se sustanciará en la misma forma y plazos que se indican para la primera instancia ....").

${ }^{76}$ Id. at 5 (“[L]os procedimientos del recurso de amparo se harán libres de costas.”).
} 
Revista Eletrônica de Direito Processual - REDP.

Rio de Janeiro. Ano 16. Volume 23. Número 1. Janeiro a Abril de 2022

Periódico Quadrimestral da Pós-Graduação Stricto Sensu em Direito Processual da UERJ

Patrono: José Carlos Barbosa Moreira (in mem.). ISSN 1982-7636. pp. 68-85

www.redp.uerj.br

(2) nongovernmental defendants. ${ }^{77}$ Incidentally, numerous regional polities exempt the latter; ${ }^{78}$ various the former. ${ }^{79}$ Therefore, Dominicans have located themselves liberally in the colloquy on scope.

In all, the implement at issue appears to signify a step forward. It might have facilitated (1) effectuating entitlements, (2) counterbalancing ordinarily formal inefficiencies, and (3) moderating a rigid civil-law proscription of judicial review. Its main drawbacks might consist in disincentivizing the creation of an efficient ordinary adjective apparatus and warding off a switch from the mentioned moderation to a termination. Palpably, they might feel less deleterious in light of the developments depicted anon. In particular, the contemplated collectivization (or aggregation) might enhance efficiency along with the reach of the collectivized (or aggregated) pronouncements. Furthermore, it might effect this enhancement as an intrinsic, not extrinsic, force in consonance with the traditional logic.

After this brief journey, one might sufficiently sense how procedurally and substantively structured guaranties might interact. The latter might promise unrestrained discourse. The former might assure enforceability in an effectual or ineffectual fashion, against a wide or narrow array of conceivable encroachers, and with or without precedential ramifications. The holder might need to know about this categorial duet and the interactions within it to decipher the extent of her entitlement. Under certain circumstances, she may have to figure out from this knowledge whether she holds a genuine right or an empty promise.

\footnotetext{
${ }^{77}$ Id. at 3 ("[La] vía [del amparo] queda abierta contra todo acto u omisión de los particulares o de los órganos o agentes de la Administración Pública, incluido la omisión o el acto administrativo, no jurisdiccional, del poder judicial, si lleva cualquiera de ellos una lesión, restricción o alteración, a un derecho constitucionalmente protegido ....").

${ }^{78}$ See, e.g., Const. art. 5 (LXIX) (Braz.); L. de la Jurisdicción Constitucional, L. 7135, art. 29 (Costa Rica) (1989); L. de Procedimientos Constitucionales, Decreto No. 1-86, art. 12 (El Sal.) (1960); L. de Amparo, Exhibición Personal y de Constitucionalidad, Decreto No. 1-86, art. 8 (Guat.) (1986); Const. art. 183 (Hond.); Const. art. 103(I) (Mex.); Const. art. 188 (Nicar.); Const. art. 54 (Pan.).

${ }^{79}$ See, e.g., L. de la Jurisdicción Constitucional, L. 7135, art. 30(b) (Costa Rica) (1989); Const. art. 200(2) (Peru); Const. art. 88 (Ecuador); L. de Procedimientos Constitucionales, Decreto No. 1-86, art. 13 (El Sal.) (1960); Const. art. 134 (Para.); Law 16011 (Uru.) (1988) art. 1(A).
} 


\section{REFERENCES:}

Argentina. Constitution (1853).

Argentina. Dec. 27, 1957, Siri, Ángel s./, [Siri v. Comisario de Policía,] Fallos: 239:459 (on file with author).

Argentina. L. 16.986 (1966).

Argentina. Sept. 5, 1958, Kot, Samuel S.R.L. s./, [Kot v. Finstein,] Fallos: 241:291 (Arg.) (on file with author).

Bolivia. Constitution (2009).

Brazil. Constitution (1988).

Capestany v. Capestany, 66 D.P.R. 764 (1946).

Charles A. Hale, The Civil Law Tradition and Constitutionalism in Twentieth Century Mexico: The Legacy of Emilio Rabasa, 18 Law \& Hist. Rev. 257, 267-268 (2000).

Chile. Constitution (1980).

Colombia. Constitution (1991).

Costa Rica. Constitution (1949).

Costa Rica. L. de la Jurisdicción Constitucional (1989).

Cuba. Constitution (2019).

Dominican Republic. Constitution (2010).

Ecuador. Constitution (2008).

El Salvador. Constitution (1983).

Emilio Rabasa, El artículo 14, estudio constitucional, y el juicio constitucional, orígenes, teoría y extensión 51-94 (5th ed. 1984).

García Fernández, ex parte, 44 D.P.R. 296 (1932).

Germany. Grundgesetz für die Bundesrepublik Deutschland.

González Natal v. Merck Sharp \& Dohme Química de Puerto Rico, Inc., 166 D.P.R. 659, 688 (2006).

Guatemala. Constitution (1985). 
Guatemala. L. de Amparo, Exhibición Personal y de Constitucionalidad. Decreto № 1-86 (1986).

Héctor Fix-Zamudio, El juicio de amparo mexicano y el recurso constitucional federal alemán (breves reflexiones comparativas), Boletín Instituto de Investigaciones Jurídicas, Nueva Serie 461-488 (Year XXVI; No. 77) (May-Aug. 1993).

Héctor Fix-Zamudio, Ensayos sobre el derecho de amparo $\S 13-24$, at 22-25 (1999).

Honduras. Constitution (1982).

Ignacio Burgoa, El Juicio de Amparo 275 (1994).

Jorge A. Rojas, Un "nuevo molde” para el amparo, 1 Revista latinoamericana de derecho 425, 426 (2004).

Jorge Alejandro Amaya, Aportes a los procedimientos de protección al consumidor que consagra el Artículo 42 de la Constitución Nacional at 4 (manuscript) (on file with author) originally published in 1 Revista jurídica de la Universidad de Ciencias Empresariales y Sociales (UCES) (primavera-verano) (1999).

Jorge Mario Quinzio Figueiredo, Justicia Constitucional en Chile 78-79 (2000).

Mexico. Acta Constitutiva y de Reformas (1847).

Mexico. Constitution (1917).

Mexico. L. de Amparo, Reglamentaria de los Artículos 103 y 107 de la Constitución Política de los Estados Unidos Mexicanos.

Mexico. L. Orgánica del Poder Judicial de la Federación (1995).

Mexico. Suprema Corte de Justicia de la Nación. Segunda Sala, Apr. 17, 2001, [Sindicato de Trabajadores de la Industria Azucarera v. Hernández Rivera,] Amparo directo en revisión, No. 1124/2000, Registro No. 7163, Semanario Judicial de la Federación y su Gaceta, Novena Época, Tomo III, Mayo de 2001, página 322 (on file with autor).

Nicaragua. Constitution (1987).

Niceto Alcalá-Zamora y Castillo, Amparo y casación 540-541 (1960).

Panama. Civil Procedure Code.

Panama. Constitution (1972).

Paraguay. Constitution (1992). 
Revista Eletrônica de Direito Processual - REDP.

Rio de Janeiro. Ano 16. Volume 23. Número 1. Janeiro a Abril de 2022

Periódico Quadrimestral da Pós-Graduação Stricto Sensu em Direito Processual da UERJ

Patrono: José Carlos Barbosa Moreira (in mem.). ISSN 1982-7636. pp. 68-85

www.redp.uerj.br

Peru. Constitution (1993).

Universal Declaration of Human Rights, G.A. Res. 217 (III) A, art. 8 (Dec. 10, 1948).

Uruguay. Constitution (1967).

Venezuela. Constitution (1999). 